\title{
Prosedur Penanganan Tindak Pidana Insider Trading Yang Dilakukan Oleh Korporasi
}

\author{
Reva Amalia \\ Magister Hukum Fakultas Hukum Universitas Islam Indonesia Yogyakarta Indonesia \\ Jln, Cik Ditiro No. 1 Yogyakarta Indonesia 55223 \\ revaamalia87@gmail.com
}

\begin{abstract}
As a modern economic instrument, the capital market is not free from abuse by certain parties to enrich themselves illegally, one of which is Insider Trading/insider trading related to the investment behavior of company employees in their own company securities. The implications and impacts of this activity include accounting, finance, law, management, human resources, and economic development. The purpose of this study is to find out about capital market crimes and insider trading, and to find out the process of resolving insider trading cases in capital market crimes committed by corporations. This research is normative in nature, the results of which conclude that: capital market crimes are acts that are prohibited within the scope of the capital market, and insider trading is securities trading; The insider trading settlement process begins with supervision carried out by OJK in accordance with Bapepam and the applicable law.
\end{abstract}

Key Words: Capital market; corporations; crimes; insider trading

\begin{abstract}
Abstrak
Sebagai instrumen ekonomi modern, pasar modal tidak luput dari penyalahgunaan oleh pihak-pihak tertentu untuk memperkaya dirinya secara melawan hukum, salah satunya yaitu Insider Trading/perdagangan orang dalam perusahaan berkaitan dengan perilaku investasi karyawan perusahaan di sekuritas perusahaan mereka sendiri. Implikasi dan dampak dari kegiatan ini meliputi akuntansi, finansial, hukum, manajemen, sumber daya manusia, dan perkembangan ekonomi. Tujuan penelitian ini untuk mengetahui mengenai tindak pidana pasar modal dan insider trading, dan untuk mengetahui proses penyelesaian perkara insider trading dalam tindak pidana pasar modal yang dilakukan oleh korporasi. Penelitian ini bersifat normatif, yang mana hasilnya menyimpulkan bahwa: tindak pidana pasar modal adalah perbuatan-perbuatan yang dilarang dalam lingkup pasar modal, dan insider trading yaitu perdagangan efek; proses penyelesaian insider trading itu diawali dengan pengawasan yang dilakukan oleh OJK sesuai dengan Bapepam dengan UU yang berlaku.
\end{abstract}

Kata-kata Kunci : Tindak pidana; pasar modal; insider trading; korporasi 


\section{Pendahuluan}

Indonesia merupakan Negara yang sedang berkembang sehingga sampai saat ini Indonesia tengah berupaya melakukan pembangunan disegala bidang guna menaikkan pertumbuhan ekonomi negara. Demi melaksanakan pembangunan ekonomi nasional dibutuhkan dana yang tidak kecil jumlahnya, kebutuhan besar pada pembangunan ekonomi nasional tidak bisa didanai oleh pemerintah saja baik melalui penerimaan pajak dan penerimaan lainnya. Artinya, terdapat sebuah alternatif sumber pembiayaan pembangunan ekonomi nasional yaitu melalui pasar modal. ${ }^{1}$

Di dalam perekonomian modern keberadaan pasar modal merupakan suatu kebutuhan. Di beberapa negara dengan keadaan perekonomian yang sudah maju, eksistensi pasar modal sebagaimana terwujud pada kelembagaan bursa efek memegang peranan krusial seperti halnya bank. Pasar modal sebagai petunjuk serta wadah bagi terjadinya interaksi antara para usahawan kepada para investor melalui suatu aktivitas ekonomi. Para usahawan yang diwakili oleh perusahaan mempunyai kebutuhan dalam rangka mencari modal dengan memasuki pasar modal. Dilain sisi, para investor atau pemodal memasuki pasar modal guna menginvestasikan dana yang dimilikinya. ${ }^{2}$

Penjelasan Undang-Undang Nomor 8 Tahun 1995 tentang Pasar Modal menyebutkan bahwa pasar modal bertujuan untuk menunjang pelaksanaan pembangunan nasional dalam rangka meningkatkan pertumbuhan, pemerataan, dan stabilitas ekonomi nasional ke arah peningkatan kesejahteraan rakyat. Untuk mencapai tujuan tersebut, pasar modal mempunyai peran strategis sebagai salah satu sumber pembiayaan bagi dunia usaha, termasuk usaha mikro, kecil, menengah (UMKM) untuk pembangunan usahanya. Sedangkan di sisi lain, pasar modal juga merupakan wahana investasi bagi masyarakat, termasuk pemodal kecil dan menengah.

Beck (2006) menyatakan bahwa, developed financial market stimulates economic growth through following factors which are firstly, it helps to mobilize and pool savings from investors, secondly, it efficiently allocates resources to the most productive uses (higher), and thirdly, it eases the exchange of goods by providing payment services, and lastly, it helps risk diversification. Selain itu, Beck menambahkan bahwa all of these

1 Jusuf Anwar, Pasar Modal Sebagai Sarana Pembiayaan dan Investasi, Alumni, Bandung, 2005, hlm. 1.

2 Inda Rahadiyan, Hukum Pasar Modal di Indonesia - Pengawasan Pasar Modal Pasca Terbentuknya Otoritas Jasa Keuangan, cet 1, UII Press, Yogyakarta, 2014, hlm. 1. 
factors must be supported by macroeconomic stability, good legal system and a free flow of information. ${ }^{3}$

Tentunya pertumbuhan pasar modal perlu didukung oleh sistem dan mekanisme yang berpijak pada aturan main yang jelas. Rule of game harus direfleksikan ke dalam bentuk ketentuan hukum yang mengatur gerak dan langkah pelaku dalam menjalankan aktivitas pasar modal. Setiap pelaku pasar, atau mereka yang menundukkan diri kepada ketentuan hukum yang berlaku di Pasar Modal, diperkenankan menciptakan atau melakukan berbagai metode dan strategi investasi, bebas berkreasi serta menjalankan berbagai jenis usaha, seperti tertuang dalam Peraturan Pemerintah Nomor 45 Tahun 1995 tentang Penyelenggaraan Kegiatan Di Bidang Pasar Modal. Kebebasan dalam menjalankan aktivitas di Pasar Modal tentunya perlu bahkan harus dibatasi oleh rambu-rambu hukum dan tata cara yang ditentukan oleh perangkat perundangundangan serta ketentuan pelaksanaan lainnya. ${ }^{4}$

Sebagai instrumen ekonomi, pasar modal tidak luput dari penyalahgunaan oleh pihak-pihak tertentu untuk memperkaya dirinya secara melawan hukum. Pasar modal baik di Indonesia maupun di negara lain sangat rawan terhadap tindak pidana seperti penipuan dan manipulasi pasar. Tindak pidana di bidang ini mempunyai kategori yang khas, antara lain adalah barang yang menjadi objek adalah informasi, selain itu pelaku tindak pidana tersebut bukanlah mengandalkan kemampuan fisik seperti halnya pencurian dan perampokan mobil, akan tetapi lebih mengandalkan pada kemampuan untuk membaca situasi pasar serta memanfaatkannya untuk kepentingan pribadi. Karakteristik lainnya yang membedakannya dengan tindak pidana lainnya yaitu pembuktiannya yang cenderung sulit dan dampak pelanggaran dapat berakibat fatal dan luas. UndangUndang Nomor 8 Tahun 1995 tentang Pasar Modal telah menggariskan jenisjenis tindak pidana di bidang pasar modal, seperti penipuan, manipulasi pasar dan perdagangan orang dalam (insider trading). ${ }^{5}$

Mengenai insider trading bahwa Perdagangan orang dalam suatu perusahaan berkaitan dengan perilaku investasi karyawan perusahaan di sekuritas perusahaan mereka sendiri. Implikasi dan dampak dari kegiatan ini meliputi akuntansi, finansial, hukum, manajemen, sumber daya manusia, dan

${ }^{3}$ Faris Njemcevic, Capital Market and Economic Growth in Transition Countries: Evidence from South East Europe, Journal of International Business Research and Marketing, vol. 2, issue 6, pp.15-22, American University in Bosnia and Herzegovina, Faculty of Finance, Bosnia and Herzegovina, September 2017, hlm. 16.

4 Prawitra Thalib, Mekanisme Penanganan Kejahatan Insider Trading, Jurnal Yuridika, Volume 27 No 2, Mei-Agustus 2012, hlm. 175.

5 M. Irsan Nasarudin dan Arman Nefi, Kejahatan dan Pelanggaran di Bidang Pasar Modal, makalah disampaikan pada Kuliah Hukum Pasar Modal, Depok, 8 Desember 2006, hlm. 3. 
perkembangan ekonomi. ${ }^{6}$ Artinya, dalam perkembangannya ternyata banyak sekali seseorang yang melakukan tindak pidana dalam ruang lingkup pasar modal ini. ${ }^{7}$

Kejahatan insider trading berdampak sangat parah dan berbahaya bagi mekanisme pasar yang fair dan efisien, karna dapat menciptakan perdangan saham yang tidak fair, yang disebabkan oleh harga saham yang tidak direfleksikan dari informasi saham yang sebenarnya sehingga mengakibatkan kerugian banyak pihak. Hal ini disebabkan informasi eksklusif yang sangat berharga mengenai kondisi perusahaan dari emiten sudah diketahui oleh publik dan yang membocorkan rahasia ini adalah orang dalam yang sangat potensial mengetahui informasi yang dimaksud. Selanjutnya terlepas bahwa informasi tersebut dipublikasikan secara sengaja atau tidak, yang terpenting tindakan tersebut dapat dikategorikan sebagai kejahatan insider trading. ${ }^{8}$

Pemaparan di atas menunjukkan bahwa permasalahan terhadap kejahatan insider trading dalam tindak pidana pasar modal yang dilakukan oleh suatu perusahaan atau korporasi dirasa harus sangat serius dikaji dalam dunia akademisi maupun praktisi, dalam rangka membangun perkembangan ekonomi yang efisien, fair serta transparan dan tentunya aman bagi seluruh pelaku ekonomi maupun pelaku usaha dibidang manapun khususnya yang berkaitan dengan pasar modal. Oleh karena itu, untuk mengetahui hal itu secara mendalam akan dipaparkan dalam penelitian ini.

\section{Rumusan Masalah}

Berdasarkan latar belakang masalah di atas, terdapat dua pokok permasalahan yang akan menjadi pokok pembahasan dari penelitian ini, yaitu : Pertama, apa yang dimaksud dengan tindak pidana insider trading? Kedua, bagaimana prosedur penanganan perkara insider trading yang dilakukan oleh korporasi?

\section{Tujuan Penelitian}

Tujuan yang akan peneliti capai dari penelitian ini adalah : pertama, untuk mengetahui apa yang dimaksud dengan tindak pidana insider trading; Kedua,

${ }^{6}$ Iain Clacher. "University of Leeds and the Centre for Advanced Studies in Finance David Hillier. University of Leeds and the Centre for Advanced Studies in Finance Sunthare Lhaopadchan. University of Amsterdam", Corporate insider trading: A literature review, Revista Española De Financiación Y Contabilidad Vol. XXXVIII, No. 143 Juli-September 2009· hal. 373 259.

${ }^{7}$ Khaerul umam, Pasar Modal Syariah \& Praktek Pasar Modal Syariah, Pustaka Setia, Bandung, 2013, hlm.

8 Simon Oloan Sitorus, “Analisis Normatif Terhadap Kejahatan Insider Trading Sebagai Predicate Crime Dalam Praktek Money Laundering”, Tesis, Universitas Sumatera Utara Medan, 2018, hlm. 23 
Untuk mengetahui prosedur penanganan perkara insider trading yang dilakukan oleh korporasi.

\section{Metode Penelitian}

Penelitian ini termasuk ke dalam penelitian hukum yang normatif yang menggunakan pendekatan perundang-undangan (Statute approach). Pendekatan ini digunakan untuk mengkaji semua perundang-undangan yang secara eksplisit memaparkan tentang pokok masalah yang dikaji. Data yang diperoleh dari hasil penelitian dianalisis menggunakan teknik deskriptif kualitatif untuk memberikan gambaran atau pemaparan atas subjek dan objek penelitian sebagaimana hasil penelitian yang dilakukannya.

\section{Hasil Penelitian dan Pembahasan}

\section{Pengertian Tindak Pidana Insider Trading}

\section{Tindak Pidana Pasar Modal}

Pada dasarnya, pasar modal menduduki fungsi sebagai perantara pihak surplus dana dengan pihak yang memerlukan dana. Word of mouth menjadi salah satu metode dalam mengenalkan pasar modal ke masyarakat. Dalam proses pengenalan, dasar pengetahuan terhadap pasar modal menjadi penting sehingga perlu adanya edukasi untuk memberikan pemahaman tersebut. Adanya edukasi akan pasar modal menjadi stimulus dalam pembuatan keputusan dengan menciptakan tidak hanya pengetahuan namun juga effort. ${ }^{9}$

Di dalam menjalankan kegiatannya, pasar modal dibagi dalam tiga macam, yaitu: ${ }^{10}$

a. Pasar Perdana, yaitu penjualan perdana efek atau penjualan efek oleh perusahaan yang menerbitkan efek sebelum efek tersebut dijual melalui bursa efek. Pada pasar perdana, efek dijual dengan harga emisi, sehingga perusahaan yang menerbitkan emisi hanya memperoleh dana dari penjualam tersebut. Menurut Surat Keputusan Menteri Kuangan Republik Indonesia No. 859/KMK.01/1987 tentang Emisi Efek Melalui Bursa bahwa yang dimaksud dengan emisi adalah suatu kegiatan menerbitkan efek untuk ditawarkan kepada masyarakat.

b. Pasar Sekunder, adalah penjualan efek setelah penjualan pada pasar perdana berakhir. Pada pasar sekunder ini harga efek ditentukan berdasarkan kurs efek tersebut. Naik turunnya kurs suatu efek

${ }_{9}$ Ririn Susilawati Zahrul Jihad, Capital Market Education Effect, Jurnal Nusantara Aplikasi Manajemen Bisnis (NUS AMBA) Program Studi Manajemen Fakultas Ekonomi Universitas Nusantara PGRI Kediri, VOL. 4 NO. 1 April 2019, hlm. 76.

10 Abdul Manan, Aspek. Hukum Dalam Penyelenggaraan Investasi di Pasar Modal Syariah Indonesia, Kencana, Jakarta, 2009, hlm. 25. 
ditentukan oleh daya tarik-menarik antara permintaan dan penawaran efek tersebut. Bagi efek yang dapat memenuhi syarat mendaftar (listing) dapat menjual efeknya di dalam bursa efek, sedangkan bagi efek yang tidak memenuhi syarat listing dapat menjual efeknya di luar bursa efek, misalnya bursa paralel (over the counter).

c. Bursa Paralel, adalah pelengkap dari bursa efek yang ada. Bagi perusahaan penerbit efek (emiten) dapat menjual efeknya melalui bursa. Tidak semua efek yang diterbitkan oleh perusahaan yang menjual sahamnya kepada masyarakat (go public) dapat menjual sahamnya di bursa efek. Ini disebabkan persyaratan untuk mendaftar di bursa efek cukup berat dan sangat ketat. Bursa paralel merupakan alternatif bagi perusahaan yang go public memperjualbelikan efeknya, apabila ia tidak mampu memenuhi persyaratan yang telah ditetapkan oleh bursa efek. Pada umumnya, efek yang didaftarkan dalam bursa paralel diterbitkan oleh perusahaan-perusahaan dengan modal relatif kecil. Perusahaanperusahaan ini perlu tambahan dana untuk membiayai investasi perusahaan, namun mereka tidak mampu memenuhi persyaratan yang ditentukan oleh bursa efek.

Bidang pasar modal ini tidak luput dari tindakan-tindakan penyalahgunaan atau perbuatan-perbuatan yang dilarang. Tindak pidana pasar modal adalah sebuah atau beberapa perbuatan didalam ruang lingkup pasar modal yang diancam dengan sanksi pidana denda maupun pidana badan. Hal ini sesuai dengan bab IX didalam Undang-Undang No. 8 Tahun 1995 tentang Pasar Modal (UUPM) antara lain meliputi tindakan penipuan, manipulasi pasar dan perdagangan orang dalam (Insider Trading). ${ }^{11}$

\section{Tindak Pidana Insider Trading}

Tindak pidana pada bidang pasar modal memiliki ciri yang spesial, yaitu diantaranya merupakan barang yang menjadi objek tindak pidana tersebut bukanlah barang dalam arti sebenarnya melainkan suatu "informasi", selain itu pelakunya tidak mengandalkan kemampuan fisik seperti halnya pencurian, perampokan, akan tetapi lebih mengandalkan kemampuan buat bisa membaca situasi pasar, dan yang lebih penting adalah pembuktiannya yang cenderung sulit. Salah satu tindak pidana pasar modal yang memerlukan kelihaian, kepandaian, dan pembuktiannya sulit adalah Insider Tranding atau perdangan orang dalam.

Insider trading secara harfiah berarti perdagangan orang dalam. Di dalam istilah hukum pasar modal, insider trading ialah perdagangan efek yang dilakukan oleh mereka yang tergolong "orang dalam" perusahaan (dalam arti

${ }^{11}$ Hamud M. Balfas, Tindak Pidana Pasar Modal dan Pengawasan Perdagangan di Bursa, Jurnal Hukum dan Pembangunan, No. 1 - 3 Tahun XXVIII, hlm. 52. 
luas), dimana perdaganan efek tersebut didasarkan karena adanya suatu "informasi orang dalam" (inside information) yang penting dan mengandung fakta material, dimana pelaku Insider Trading (Inside Trader) mengharapkan laba ekonomi secara langsung ataupun tidak langsung. Insider trading is the sale or purchase of securities by corporate insiders, using monopolistic information to their advantage to generate abnormal returns. Monopolistic information is privileged, price sensitive, and material nonpublic information. Material refers to information which is likely to affect significantly the market price of the issuing company's securities or which is likely to be considered important by reasonable investors in determining whether to trade a particular security. ${ }^{12}$

Praktik insider trading ialah salah satu praktik yang melanggar prinsip keterbukaan pada kegiatan pasar modal. Selain itu, praktik itu juga sebagai praktik perdagangan saham yang tidak adil (unfair trading) sebab posisi inside trader yang lebih baik (pada kepemilikan informational advantages) dibandingkan investor lain.

Undang-Undang Nomor 8 Tahun 1995 tentang Pasar Modal telah menggariskan jenis- jenis tindak pidana di bidang pasar modal, seperti penipuan, manipulasi pasar dan perdagangan orang dalam (insider trading). Dalam Pasal 95 menyebutkan bahwa orang dalam dari emiten atau Perusahaan Publik yang mempunyai informasi orang dalam dilarang melakukan pembelian atau penjualan atas Efek: a. Emiten atau Perusahaan Publik dimaksud; atau b. perusahaan lain yang melakukan transaksi dengan Emiten atau Perusahaan Publik yang bersangkutan.

Pasal 96 juga menegaskan terkait larangan-larangan yang dilakukan oleh orang dalam sebagaimana didalam Pasal 95 di atas, larangan-larangan tersebut antara lain yaitu:

a. mempengaruhi Pihak lain untuk melakukan pembelian atau penjualan atas Efek dimaksud; atau

b. memberi informasi orang dalam kepada Pihak mana pun yang patut diduganya dapat menggunakan informasi dimaksud untuk melakukan pembelian atau penjualan atas Efek.

Sean P. Leuba berpendapat mengenai Kategori-kategori insider yang umumnya terdiri dari komisaris, direktur, pemegang saham utama serta pegawai perusahaan merupakan contoh klasik dari penentuan insider dalam fiduciary duty theory atau yang dikenal dengan traditional insiders. ${ }^{13} \mathrm{Hal}$ ini

12 Ako Doffou, CFA, Peter F. Drucker, Insider Trading: A Review of Theory and Empirical Work, Journal of Accounting and Finance Research, Vol. 11, No 1, Spring 2003, Claremont Graduate University, California.

13 Bismar Nasution, Keterbukaan Dalam Pasar Modal, Fakultas Hukum Universitas Indonesia, Program Pascasarjana, Jakarta, 2001, hlm. 261. 
juga sesuai seperti yang tertera didalam penjelasan Pasal 95 UUPM. Selanjutnya akan peneliti bahas mengenai proses penyelesaian perkara insider trading tersebut di bawah ini.

Ada beberapa hal yang digunakan sebagai dasar mengapa insider trading ini harus dilarang, yaitu pertama, insider trading berbahaya bagi mekanisme pasar yang fair dan efisien karena pembentukan harga yang tidak fair dan perlakuan tidak adil diantara para pelaku pasar, kedua, insider trading berdampak negatif bagi emiten, ketiga, kerugian materiil bagi investor, dan keempat, kerahasiaan itu milik perusahaan. ${ }^{14}$

\section{Prosedur Penanganan Tindak Pidana Insider Trading yang Dilakukan oleh Korporasi}

Mengacu pada proses penyelesaian tindak pidana insider trading yang dilakukan oleh korporasi, dimana korporasi sebagai badan hukum juga dapat dimintai pertanggung jawaban pidana nya sesuai dengan ketentuan UndangUndang No. 8 Tahun 1995 tentang Pasar Modal atau yang biasa disingkat sebagai UUPM, pada Pasal 1 angka 23 UUPM menjelaskan bahwa pihak adalah orang perseorangan, perusahaan, usaha bersama, asosiasi, atau kelompok yang terorganisasi. Dengan begitu maka korporasi pada tindak pidana pasar modal adalah juga merupakan subjek hukum yang dapat dimintai pertanggung jawaban atas suatu tindak pidana yang dilakukannya, dalam hal ini yaitu insider trading.

Wewenang pemeriksaan dan penyidikan tindak pidana insider trading diberikan kepada lembaga BAPEPAM, sebagaimana diatur dalam Pasal 100 dan Pasal 101. Terkait hal ini, Pasal 100 mengatur bahwa Bapepam dapat mengadakan pemeriksaan terhadap setiap Pihak yang diduga melakukan atau terlibat dalam pelanggaran terhadap undang-undang ini dan atau peraturan pelaksanaannya. Untuk melakukan pemeriksaan tersebut, Bapepam mempunyai wewenang untuk:

a. meminta keterangan dan atau konfirmasi dari Pihak yang diduga melakukan atau terlibat dalam pelanggaran terhadap undang-undang ini dan atau peraturan pelaksanaannya atau Pihak lain apabila dianggap perlu;

b. mewajibkan Pihak yang diduga melakukan atau terlibat dalam pelanggaran terhadap Undang-undang ini dan atau peraturan pelaksanaannya untuk melakukan atau tidak melakukan kegiatan tertentu;

c. memeriksa dan atau membuat salinan terhadap catatan, pembukuan, dan atau dokumen lain, baik milik Pihak yang diduga melakukan atau terlibat dalam pelanggaran terhadap Undang-undang ini dan atau peraturan pelaksanaannya

14 Berinda Sylvia Raganatha, "Tinjauan Pertanggungjawaban Pidana Bagi Korporasi Yang Melakukan Insider Trading Dalam Pasar Modal”, Jurnal Refleksi Hukum Universitas Kristen Satya Wacana, Vol. 2, No. 1, 2017, hlm, 22. 
maupun milik Pihak lain apabila dianggap perlu; dan atau

d. menetapkan syarat dan atau mengizinkan Pihak yang diduga melakukan atau terlibat dalam pelanggaran terhadap Undang-undang ini dan atau peraturan pelaksanaannya untuk melakukan tindakan tertentu yang diperlukan dalam rangka penyelesaian kerugian yang timbul.

Pasal tersebut juga mengatur bahwa setiap pegawai Bapepam yang diberi tugas atau Pihak lain yang ditunjuk oleh Bapepam untuk melakukan pemeriksaan dilarang memanfaatkan untuk diri sendiri atau mengungkapkan informasi yang diperoleh berdasarkan Undang-undang ini kepada Pihak mana pun, selain dalam rangka upaya mencapai tujuan Bapepam atau jika diharuskan oleh Undangundang lainnya.

Penyidikan tindak pidana insider trading dilakukan dengan mengacu apda ketentuan Pasal 101 sebagai berikut:

(1) Dalam hal Bapepam berpendapat pelanggaran terhadap undang-undang ini dan atau peraturan pelaksanaannya mengakibatkan kerugian bagi kepentingan Pasar Modal dan atau membahayakan kepentingan pemodal atau masyarakat, Bapepam menetapkan dimulainya tindakan penyidikan.

(2) Pejabat Pegawai Negeri Sipil tertentu di lingkungan Bapepam diberi wewenang khusus sebagai penyidik untuk melakukan penyidikan tindak pidana di bidang Pasar Modal berdasarkan ketentuan dalam Kitab Undang-undang Hukum Acara Pidana.

(3) Penyidik sebagaimana dimaksud dalam ayat (2) berwenang :

a. menerima laporan, pemberitahuan, atau pengaduan dari seseorang tentang adanya tindak pidana di bidang Pasar Modal;

b. melakukan penelitian atas kebenaran laporan atau keterangan berkenaan dengan tindak pidana di bidang Pasar Modal;

c. melakukan penelitian terhadap Pihak yang diduga melakukan atau terlibat dalam tindak pidana di bidang Pasar Modal;

d. memanggil, memeriksa, dan meminta keterangan dan barang bukti dari setiap Pihak yang disangka melakukan, atau sebagai saksi dalam tindak pidana di bidang Pasar Modal;

e. melakukan pemeriksaan atas pembukuan, catatan, dan dokumen lain berkenaan dengan tindak pidana di bidang Pasar Modal;

f. melakukan pemeriksaan di setiap tempat tertentu yang diduga terdapat setiap barang bukti pembukuan, pencatatan, dan dokumen lain serta melakukan penyitaan terhadap barang yang dapat dijadikan bahan bukti dalam perkara tindak pidana di bidang Pasar Modal;

g. memblokir rekening pada bank atau lembaga keuangan lain dari Pihak yang diduga melakukan atau terlibat dalam tindak pidana di bidang Pasar Modal;

h. meminta bantuan ahli dalam rangka pelaksanaan tugas penyidikan tindak pidana di bidang Pasar Modal; dan

i. menyatakan saat dimulai dan dihentikannya penyidikan. 
(4) Dalam rangka pelaksanaan penyidikan sebagaimana dimaksud dalam ayat (1), Bapepam mengajukan permohonan izin kepada Menteri untuk memperoleh keterangan dari bank tentang keadaan keuangan tersangka pada bank sesuai dengan peraturan perundang-undangan di bidang perbankan.

(5) Penyidik sebagaimana dimaksud dalam ayat (2) memberitahukan dimulainya penyidikan dan menyampaikan hasil penyidikannya kepada penuntut umum sesuai dengan ketentuan yang diatur dalam Kitab Undang-undang Hukum Acara Pidana.

(6) Dalam rangka pelaksanaan kewenangan penyidikan sebagaimana dimaksud dalam ayat (1), Bapepam dapat meminta bantuan aparat penegak hukum lain.

(7) Setiap pejabat Pegawai Negeri Sipil tertentu di lingkungan Bapepam yang diberi tugas untuk melakukan penyidikan dilarang memanfaatkan untuk diri sendiri atau mengungkapkan informasi yang diperoleh berdasarkan Undang-undang ini kepada Pihak mana pun, selain dalam rangka upaya untuk mencapai tujuan Bapepam atau jika diharuskan oleh Undangundang lainnya.

Pemaparan di atas menunjukkan bahwa pihak yang berwenang melakukan pemeriksaan awal dan penyidikan terhadap pelanggaran ataupun tindak pidana didalam pasar modal, yaitu dilakukan oleh lembaga BAPEPAM (Badan Pengawas Pasar Modal). Kemudian Perlu diketahui bahwa yang melakukan tindak pidana insider trading didalam korporasi atau perusahaan seperti yang sudah peneliti sampaikan diatas, yaitu biasanya merupakan pihak komisaris, direktur, pemegang saham utama serta pegawai perusahaan, dan sebagainya.

Suatu korporasi atau perusahaan yang terbukti bersalah dalam melakukan perdagangan orang dalam (insider trading), dapat di pidana sesuai dengan ketentuan Pasal 104 UUPM yaitu diancam dengan pidana penjara paling lama 10 tahun dan denda paling banyak Rp15.000.000.000,00 "Setiap Pihak yang melanggar ketentuan sebagaimana dimaksud dalam Pasal 90, Pasal 91, Pasal 92, Pasal 93, Pasal 95, Pasal 96, Pasal 97 ayat (1), dan Pasal 98 diancam dengan pidana penjara paling lama 10 tahun dan denda paling banyak Rp. 15.000.000.000,00".

Ketentuan terkait prosedur penanganan tindak pidana yang melibatkan korporasi juga diatur dalam Perma No. 13 Tahun 2016 tentang Tata Cara Penanganan Perkara Tindak Pidana oleh Korporasi. Perma tersebut mengatur bahwa pidana pokok yang dapat dijatuhkan pada korporasi yaitu hanya berupa pidana denda, sebagaiman diatur dalam Pasal 25 Perma tersebut. Artinya, tindak pidana insider trading yang dilakukan oleh korporasi hanya dapat dijatuhi sanksi pidana berupa pidana denda yang besarnya sesuai dengan Pasal 104 UndangUndang Pasar Modal dengan denda maksimal Rp. 15.000.000.000,00. 


\section{Penutup}

Berdasarkan pembahasan di atas dapat disimpulkan bahwa, pertama, tindak pidana pasar modal adalah sebuah atau beberapa perbuatan didalam ruang lingkup pasar modal yang diancam dengan sanksi pidana denda maupun pidana badan. Sedangkan Insider trading secara harfiah artinya perdagangan orang dalam. Di dalam arti hukum pasar modal, Insider Trading ialah perdagangan efek yang dilakukan seseorang yang tergolong "orang dalam" perusahaan, yang melanggar prinsip dan aturan pada pasar modal.

Kedua, prosedur penanganan tindak pidana insider trading bermula pada pemeriksaan serta penyidikan yang wewenangnya telah diberikan oleh BAPEPAM. Kemudian apabila tindak pidana tersebut dilakukan oleh korporasi, Pasal 1 angka 23 UUPM telah mengatur bahwa korporasi juga ditetapkan sebagai subjek hukum pada pasar modal, dengan demikian maka korporasi sebagai subjek hukum dapat dimintai pertanggung jawaban atas tindak pidana insider trading yang dilakukannya tersebut. Selain itu, Perma No. 13 Tahun 2016 tentang Tata Cara Penanganan Perkara Tindak Pidana oleh Korporasi mengatur bahwa pidana yang dapat dijatuhkan kepada korporasi yang melakukan tindak pidana adalah pidana denda. Jadi, sesuai dengan aturan pada UUPM Pasal 104 dimana korporasi sebagai pelaku tindak pidana insider trading (perdagangan orang dalam) dapat dikenakan pidana berupa pidana denda maksimal Rp. 15.000.000.000,00.

\section{Saran}

Perlu adanya amandemen hukum terhadap pasar modal terkait kejahatan insider trading yang cukup rumit agar lebih mendalam pengaturannya sehingga kejahatan ini dapat ditangani dengan serius dan memberikan efek jera bagi para pelakunya.

\section{Daftar Pustaka}

\section{Buku}

Anwar, Jusuf, Pasar Modal Sebagai Sarana Pembiayaan dan Investasi, Alumni, Bandung, 2005.

Bestari, Abaraham, Insider Trading, Badan Pengawasan Pasar Modal, Jakarta, Februari 2004.

Fuady, Munir, Doktrin-Doktrin Modern Dalam Corporate Law dan Eksistensinya Dalam Hukum Indonesia, Citra Aditya Bakti, Bandung, 2010.

Husein, Yunus, Sambutan Kepala PPATK, dalam Seluk Beluk Tindak Pidana Pencucian Uang dan Pembiayaan Terorisme, PT. Pusaka Utama Grafiti, Jakarta, 2004. 
Manan, Abdul, Aspek Hukum Dalam Penyelenggaraan Investasi di Pasar Modal Syariah Indonesia, Kencana, Jakarta, 2009.

Nasarudin, M. Irsan dan Indra Surya, Aspek Hukum Pasar Modal Indonesia, Kencana, Jakarta, 2010.

Nasution, Bismar, Keterbukaan Dalam Pasar Modal, Fakultas Hukum Universitas Indonesia, Program Pascasarjana, Jakarta, 2001.

Rahadiyan, Inda, Hukum Pasar Modal di Indonesia-Pengawasan Pasar Modal Pasca Terbentuknya Otoritas Jasa Keuangan, UII Press, Yogyakarta, 2014.

Umam, Khaerul, Pasar Modal Syariah E Praktek Pasar Modal Syariah, Pustaka Setia, Bandung, 2013.

Jurnal, Makalah, dan Hasil Penelitian

Ako Doffou dan Peter F. Drucker, Insider Trading: A Review of Theory and Empirical Work, Journal of Accounting and Finance Research, Vol. 11, No 1, Spring 2003, Claremont Graduate University, California.

Barda Nawawi Arief, "Tindak Pidana Pencucian Uang dan Tindak Pidana Lainnya Yang Terkait", Jurnal Hukum Bisnis, Vol. 2 No. 3, Yayasan Pengembangan Hukum Bisnis, Jakarta, 2003

Faris Njemcevic, "Capital Market and Economic Growth in Transition Countries: Evidence from South East Europe", Journal of International Business Research and Marketing, vol. 2, issue 6, pp.15-22, American University in Bosnia and Herzegovina, Faculty of Finance, Bosnia and Herzegovina, September 2017

Firman Halawa, \& Marlina, Upaya Penegakan Hukum Atas Insider Trading Sebagai Kejahatan Asal (Predicate Crime) Dalam Tindak Pidana Pencucian Uang. Jurnal Mercatoria Vol. 5 No. 2 Tahun 2012

Hamud M Balfas, "Tindak Pidana Pasar Modal dan Pengawasan Perdagangan di Bursa", Jurnal Hukum dan Pembangunan No. 1 - 3 Tahun XXVIII

Iain Clacher, "Corporate insider trading: A literature review, Revista Española De Financiación Y Contabilidad", Journal University of Leeds and the Centre for Advanced Studies in Finance David Hillier. University of Leeds and the Centre for Advanced Studies in Finance Sunthare Lhaopadchan. University of Amsterdam Vol. XXXVIII, No. 143 Juli-September 2009

M. Irsan Nasarudin dan Arman Nefi, Kejahatan dan Pelanggaran di Bidang Pasar Modal, makalah disampaikan pada Kuliah Hukum Pasar Modal, Depok, 8 Desember 2006

Mohammed Aminu Bello, "Market Reaction and Insider Trading Around the Announcements of Equity Issues: Evidence from Nigeria", International Journal of Accounting, Department of Business Administration and Entrepreneurship, Bayero University, Kano, Nigeria, Finance and Risk Management December 2016.

Ririn Susilawati Zahrul Jihad, "Capital Market Education Effect", Jurnal Nusantara Aplikasi Manajemen Bisnis (NUSAMBA) Program Studi 
Manajemen Fakultas Ekonomi Universitas Nusantara PGRI Kediri", VOL. 4 NO. 1 April 2019.

Sutan Remy Sjahdeni, "Pencucian Uang: Pengertian, Sejarah, Faktor-Faktor Penyebab, dan Dampaknya Bagi Masyarakat", Jurnal Hukum Bisnis Vol. 22 No. 3, Yayasan Pengembangan Hukum Bisnis, Jakarta, 2003.

Utpal Bhattacharya and Hazem Daouk, "The World Price of Insider Trading", The Journal of Finance, Vol-I.VII, No. 1, The Hongkong University of science and Technology, Februari 2002. 